\title{
Induction of Novel Mutants and their Stability Using Gamma Irradiation in Tuberose (Polyanthes tuberosa L)
}

\author{
R. Jyothi*, K.P. Singh, T. Mohapatra and N. Kiran Kumar \\ ICAR-Krishi Vigyan Kendra, Koppal - 583227, Karnataka, India \\ *Corresponding author
}

\begin{tabular}{|l|}
\hline Ke y w o r d s \\
Tuberose, Novel \\
mutant, Stability, \\
Gamma irradiation
\end{tabular}

\section{A B S T R A C T}

A study was conducted to find out the novel mutants induced by the gamma irradiation in tuberose crop. The experiment was carried out at the Indian Agricultural Research Institute, New Delhi. Two cultivars Prajwal and PhuleRajani with three bulb stages were selected freshly harvested bulb $\left(\mathrm{B}_{0}\right)$, three weeks after uprooting $\left(\mathrm{B}_{1}\right)$ and six weeks after uprooting $\left(B_{2}\right)$ were irradiated by $\mathrm{G}_{1}-2.5 \mathrm{~Gy}, \mathrm{D}_{2}-5.0 \mathrm{~Gy}, \mathrm{G}_{3}-7.5 \mathrm{~Gy}, \mathrm{G}_{4}-10.0 \mathrm{~Gy}$ and $\mathrm{G}_{5}-15.0$ Gy of gamma rays along with control $\left(\mathrm{G}_{0}-\mathrm{OGy}\right)$ without irradiation. Gamma radiation affected the sprouting in variety Prajwal where above 2.5 Gy there was no bulb sprouting was observed. This was supported by the histological study where cells become bigger in size, deformed shape of the cell, complete damage of outer epidermal layer and cells with more vaculation was observed. New mutants were isolated from VM1 generation Viz., Tall flowering mutant, dwarf mutant, Flower colour mutant, Double spike head mutant even though these mutant were novel but they were not found stable in next generation. In VM2 population mutants were derived from the primary gamma irradiated population which was maintained after observing the gamma irradiation effect of $\mathrm{vM}_{1}$ generation Viz., Flower shape mutant, Tall mutant, Flower colour Mutant, Mutant with higher rachis length and variegated leaf mutant. From this study it was found that freshly harvested bulbs of both the tuberose cultivars Prajwal and PhuleRajani are highly suitable for mutation induction either in vivo and also in vitro condition.

\section{Introduction}

Floriculture is a fast emerging major venture in the commercial world, growing at the modest rate of $10-15$ per cent. Ornamental bulbs, one of the most beautiful and variable group of geophytes, have been appreciated from ancient times. Tuberose (Polianthes tuberosa Linn.) is one of the most important bulbous flowering plant of tropical and subtropical areas, it is monocot genus, perennial, bulbous plant (Rose 1903, Bailely 1939). In
India, tuberose is being commercially cultivated over more than 30,000 ha area (Singh et al., 2010). There are some species with different range in colour from white, orange red, red, red to strip. All the species are wild with the exception of P.tuberosa which has never been found anywhere except under cultivation. Polianthes tuberosa occupies a prime position owing to its popularity as a cut flower, loose flower and also raw material for extraction of the highly valued natural flower oil. The serene beauty of the flower is because 
of its tall and straight spikes which bear bright white florets which are loosely arranged on spike that can reach 3-4 feet in height. Named cultivars are very few in tuberose and they derive their name from the number of row of petals each flower possesses viz., Singlecultivar with a single row of petals; Doublethe one which bears more than three rows of petals; Semi-double-cultivar bears flower with two to three rows of petals. The genetic variability in tuberose is very limited and it has narrow genetic base.

The genetic variability is necessary in any plant breeding programme for crop improvement. Non-availability of genetic variability has become a major constraint in conventional breeding of tuberose (Anu et al., 2003). Genetic improvement of tuberose is hampered by meager genetic variability, selfincompatibility and seed sterility. Seed set is also observed only a few Single type cultivars with limited seed set and poor germination. To achieve the rapid evolution needed by the plant breeders for satisfying the rapidly changing needs, more rapid generation of new genetic forms is required. Such requirements for large amount of new genetic variability can only be met with the aid of induced mutations as supplements to natural genetic resources. Induction of mutation is an important pathway for the production of new genotypes in vegetatively propagated species and to enhance genetic resource. Compared to chemical mutagen physical mutagen gamma radiation have provided an high number of useful mutants and is still showing an elevated potential for improving vegetative propagated plants. Ionizing radiations normally causes chromosomal rearrangements and deletions (Bhat et al., 2007). Nevertheless the induced mutants have been released in ornamentals; systematic studies on the radio sensitivity of vegetatively propagated plants are scanty. Presently, variability is created artificially through tinting using artificial colours/dyes, which are often poisonous. Keeping these in view the present investigation is proposed to be carried out with the objective to induce novel mutants using gamma irradiation in tuberose and selection of novel types based on important traits and to check the inheritance and stability of characters expressed in $\mathbf{M}_{1}$ generation in $\mathrm{M}_{2}$ generation.

\section{Materials and Methods}

To evaluate the optimal gamma irradiation dosage to induce the attractive mutant and their stability in tuberose (Polianthes tuberose L.) a field experiment was conducted in 2008 , 2009, 2010 and 2011 at the Indian Agricultural Research Institute, New Delhi. Cultivars Prajwal and PhuleRajani were selected for the study. Both these cultivars are of Single type with high superior quality of loose and cut flower production. Bulbs of these two cultivars were collected from Research Farm of Division of Floriculture and Landscaping. In order to obtain the new novel mutants three different bulb stages viz., freshly harvested bulb $\left(\mathrm{B}_{0}\right)$, three weeks after uprooting $\left(\mathrm{B}_{1}\right)$ and six weeks after uprooting $\left(B_{2}\right)$ were irradiated by $G_{1}-2.5 G y, D_{2}-5.0 G y$, $\mathrm{G}_{3}-7.5 \mathrm{~Gy}, \mathrm{G}_{4}-10.0 \mathrm{~Gy}$ and $\mathrm{G}_{5}-15.0 \mathrm{~Gy}$ of gamma rays along with control $\left(\mathrm{G}_{0^{-}}\right.$ 0Gy)without irradiation at Gamma Chamber, Nuclear Research Laboratory, IARI, New Delihi. The experiment was laid out in randomized block design with three replication. The treated bulbs as well as untreated bulbs (control) were planted on the same day. The $\mathrm{B}_{0}$ and $\mathrm{B}_{1}$ stages bulbs of both tuberose cultivars were planted on $12^{\text {th }}$ March 2009. The $B_{2}$ stage bulbs of both tuberose cultivars were planted on $2^{\text {nd }}$ April 2009. LD $_{50}$ (Lethal dose-50) was determined on the basis of the plants sprouted in each treatment. Any variations appearing in the treated plants different from the control were recorded. The plants growth was observed regularly for the variation such as differences in size, shape or 
chlorophyll distribution or any other variations of vegetative origin were recorded.

In order to find out the cause for nonsprouting of cv. Prajwal bulbs ( $\mathrm{B}_{1}$ stage) beyond 2.5 Gy of gamma irradiation, histology study was done at National Bureau of Plant Genetic Resources IARI. For histological study three weeks old bulbs of cv. Prajwal were selected and irradiated with the levels of gamma radiation i.e. 5.0Gy, 7.5Gy and 10.0Gy. The central growing buds of these irradiated bulbs were fixed by keeping into FA solution for 48 hours. The fixed samples are stored in 70 per cent alcohol. These fixed tissues are subjected to dehydration and staining protocol. The prepared blocks were cut into equal sized cubes and microtomy performed using microtome machine LEICA RM 2162, Leica. And the slides were prepared using Houpts solution. These slides were made to follow staining protocol using fast green. Once the staining was over DPX mounting was done. These permanent slides were observed under compound microscope (Imager 1A, AX10) to notice the change which was induced in the bulb cells of cv. Prajwal by gamma irradiation. The microscopic observations were recorded for the histology study with respect to per cent damage to the cells, Shape for the cells, Shape of the nucleous, and Size of the cells.

Further in the field condition careful observations were made to record any change in flower character of gamma irradiated plants with respect to each treatment viz., Variation in floral colour, size, shape, number of floral organs and variation in spike stem. On the basis of this also some useful mutants were selected.

For the stability bulbs from the plants which have showed variation in the $\mathrm{vM}_{1}$ generation were uprooted on first week of January 2010.
These bulbs are stored under normal room temperature for about 40 days. The bulbs of particular plant which had showed the variation are planted in $1 \times 1 \mathrm{~m}$ plots on $25^{\text {th }}$ of February 2010. The following observations were recorded:

Per cent sprouting

Stem, leaf variation

Variation in flower colour, Size, shape number of floral organs and variation in stock of the spike

The first generation plants which showed good and acceptable variation were also taken care to observe their performance in the $\mathrm{vM}_{2}$ generation.

Mutants during vM1 generation and their stability

Mutants in vM2 generation from the primary gamma irradiated population

\section{Results and Discussion}

\section{Sprouting per cent}

$\mathrm{B}_{1}$ bulb stage (three weeks after uprooting) of cv. Prajwal was found highly sensitive to gamma irradiation, there was no sprouting observed beyond 2.5 Gy (Figure 1). This higher radio sensitivity could be due to their less developed meristems (Katagiri and Lapins, 1974). Whereas in cv. PhuleRajani (Figure 2). The three weeks after uprooted bulbs stage $\left(B_{1}\right)$ responded to all the doses of gamma irradiation and significant decrease in sprouting was observed above $2.5 \mathrm{~Gy}$. The fact for lower sprouting at higher dose of gamma irradiation could be level of auxin concentration in plants which drops after exposure to ionizing radiation (Skooge 1935, Gorden 1957). 


\section{Results of histological study}

First Histology study was conducted this study is first of its kind to find out effect of gamma irradiation beyond 2.5 Gy for three weeks after uprooted bulbs (B1) of cv. Prajwal that had resulted in complete mortality. The result of the histology study is presented in Plates 12 and 13 . We have observed that cells irradiated with 5.0 Gy, 7.5 Gy and 10.0 Gy gamma radiation severely affected. In non-irradiated tissue we observed the cells were arranged properly with nucleus in them. But, after irradiation about $90 \%$ cells were without nucleus. The cells become bigger in size and the shape deformed. Irradiation with 10.0 Gy of gamma irradiation caused complete damage of outer epidermal layer (Figure 3). Most of the bundle sheath cells were damaged at 5.0 Gy and above doses of gamma radiation. In one of the slide we observed cells with more vaculation were also devoid of nucleus.

\section{Leaf and plant abnormalities}

At higher gamma irradiation dose (10.0 Gy) we have observed leaf abnormalities like crinkled leaf, golden yellow and white margin in one side of the leaf. A similar phenomenon was reported by Gunkel and Sparrow (1954). These abnormalities are determined to the behaviour of tissues at different phases of development (Hansel, 1966). These are mainly due to the mutagenic effects on cell division chromosomal breakage and damage, damage to auxins (Gorden, 1957) or due to change in biochemical products of the plant (Steinberg 1956). Kawai and Sato (1966) reported that the increase in mutation frequency has been shown to be accomplished by the injuries in $\mathrm{M}_{1}$ plants. Plant abnormalities like reduced plant height, rosette form of plant and multiple sprouting from single bulbs were observed Similar results was obtained by Yekta et al., 2016. It was observed that at lower dose of gamma irradiation $2.5 \mathrm{~Gy}$ and 5.0 Gy there was no reduction in the chlorophyll content across the bulbs stages in both tuberose cultivars. There was slight reduction of the chlorophyll content was observed at 7.5 and 10.0 Gy of gamma irradiation doses. Similar results were reported earlier by Banerji et al., (1994) in gladiolus. This may be caused by the reduced amount of endogenous growth regulators, especially the cytokinin, because of breakdown or lack of synthesis due to irradiation (Omar, 1988). Reduction in growth can also be explained as differential killing of meristematic cells due to genetic injury, with damage cells producing less cell progenies (Sparrow et al., 1952, Hagberg and Nybom, 1954).

\section{Flower and spike variations in $\mathrm{vM}_{1}$ generation}

In the present study variations in flower were recorded like reduced petal number and increased petal number than normal and change in the flower tube shape in both the cultivars. Similar result was recorded by Datta (2000) in tuberose. It was observed that the frequency of this kind of petals was more in lower florets of the spike and upper florets had normal petal number. Similar study observed with respect to mutation frequency in gladiolus (Buiatti et al., 1969), when they calculated the mutation frequency per flower it decreased from the bottom to the top of the spike and this was not found to be constant throughout the plants. Deformed spikes and change in the floret arrangement was also observed in some irradiated plants.

These types of abnormalities were observed by Marek (1959) in gladiolus. The assumption one can make that the damage would be caused at the tip of the flower primordial differentiation. Complete blindness of plants shows severe damage in the synthesis of growth substance like auxins and other growth regulators (Skoog, 1935). 


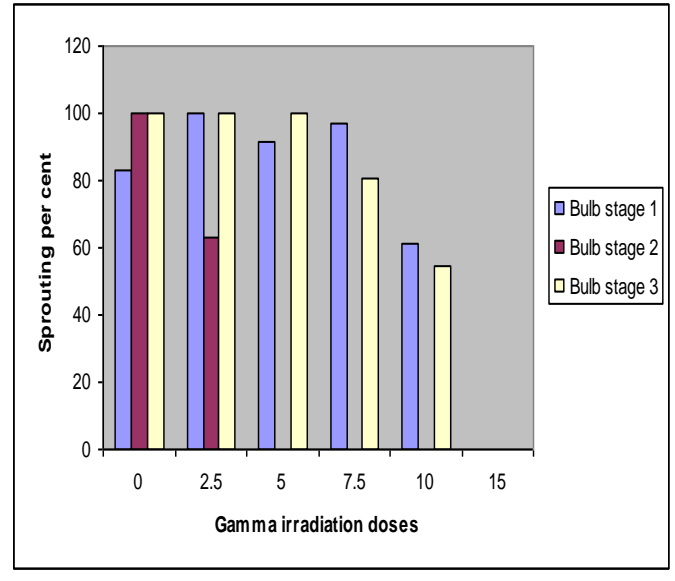

Fig.1. Sprouting per cent of cv. Prajwal in all three bulb stages

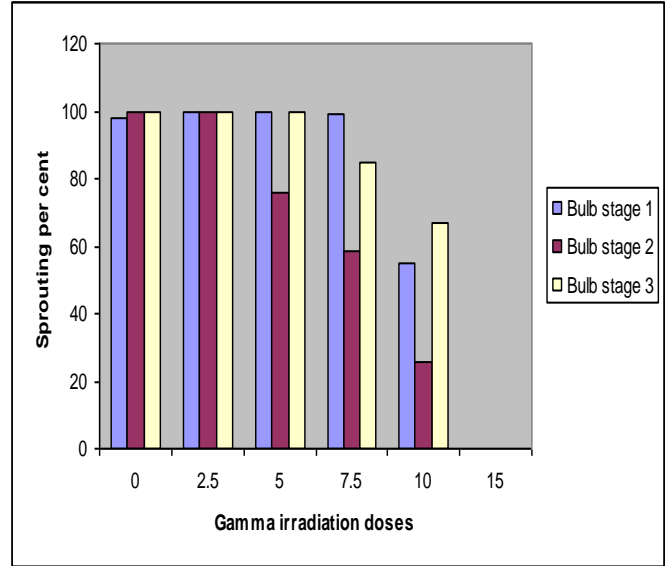

Fig.2. Sprouting per cent of cv. Phule Rajani in all three bulb stages
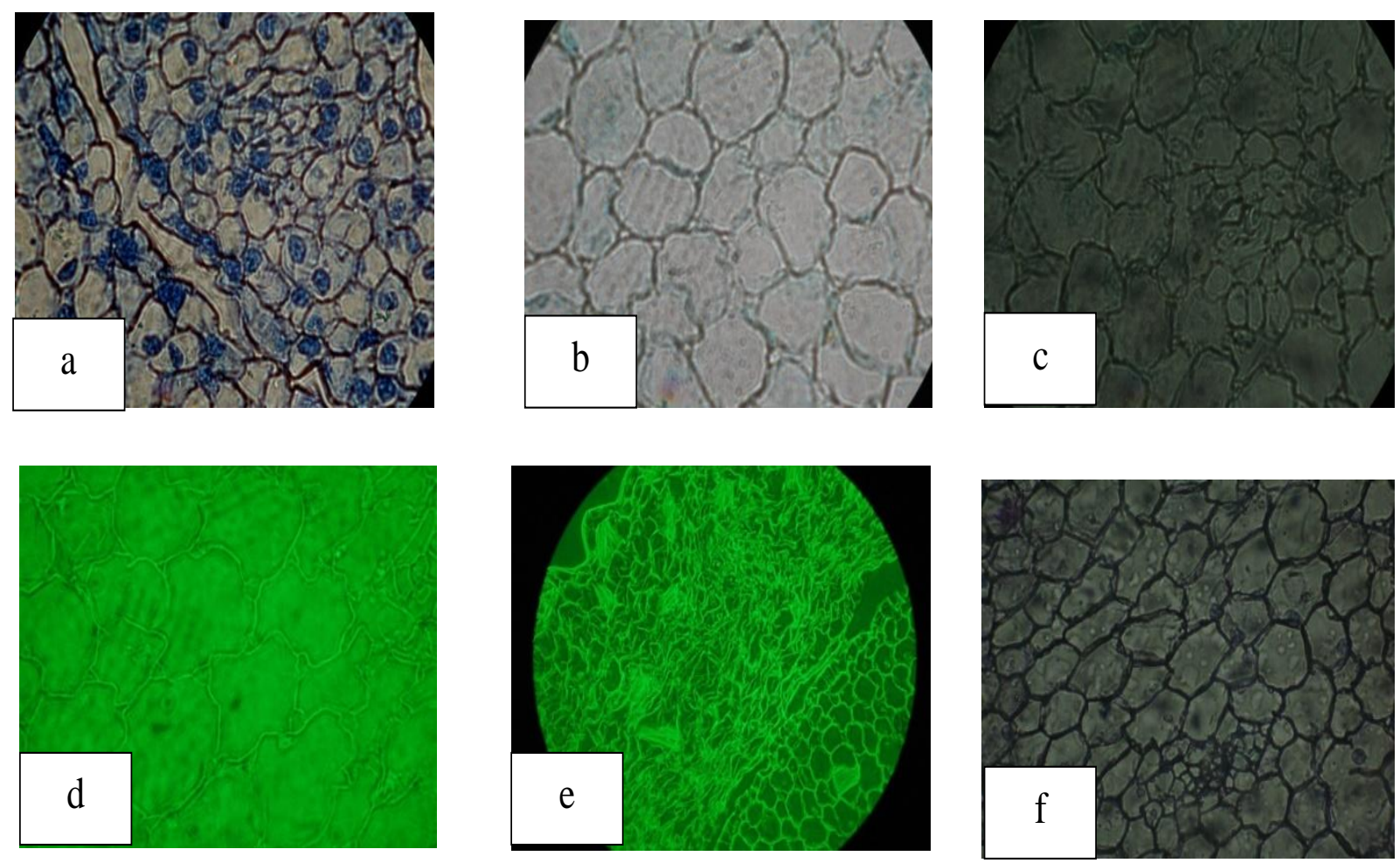

Figure 3:a) Cell arrangement in non-irradiated tissue. b, c \& d) non nucleated deformed cells after irradiation e) Tissue with totally damaged outer cell layer f) Increased vacuolation inside the cells 

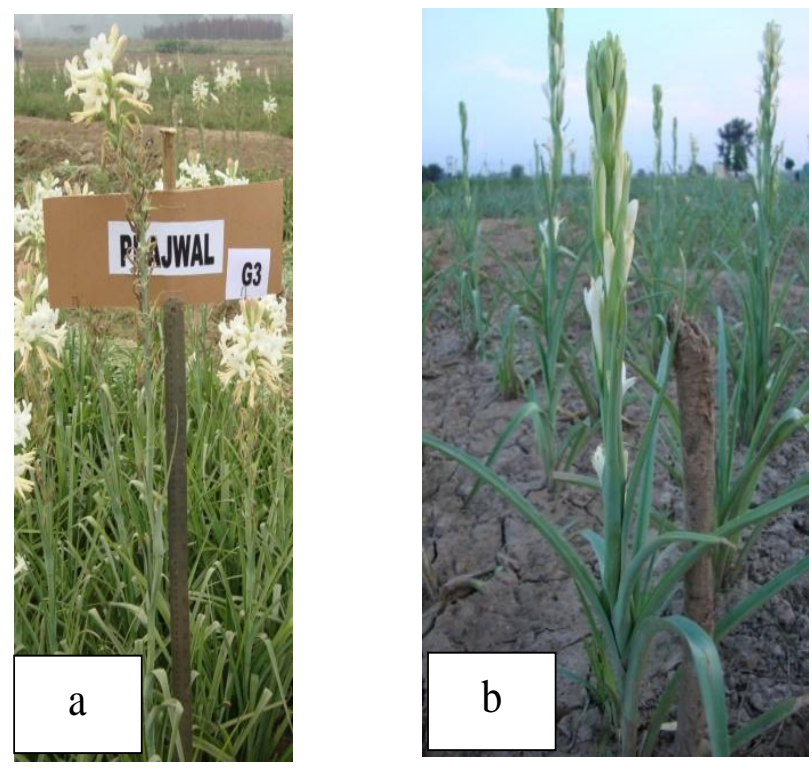

Figure 4: Long and short spike mutants induced by gamma Irradiation (7.5 Gy) in cvs. Prajwal and PhuleRajani at $\mathrm{B}_{2}$ bulb stage in $\mathrm{VM}_{1}$ generation
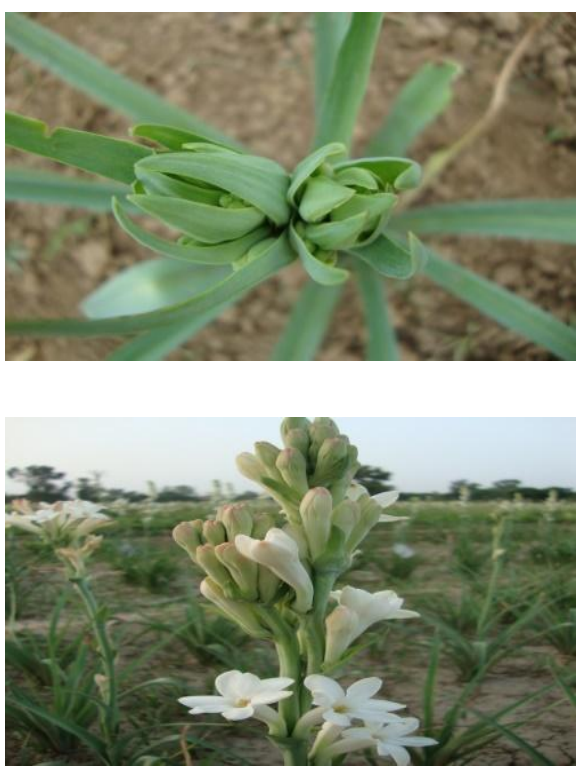

Figure 5. Double spike head formation in cv. Prajwal at $\mathrm{B}_{2}$ bulb stage $(7.5 \mathrm{~Gy})$
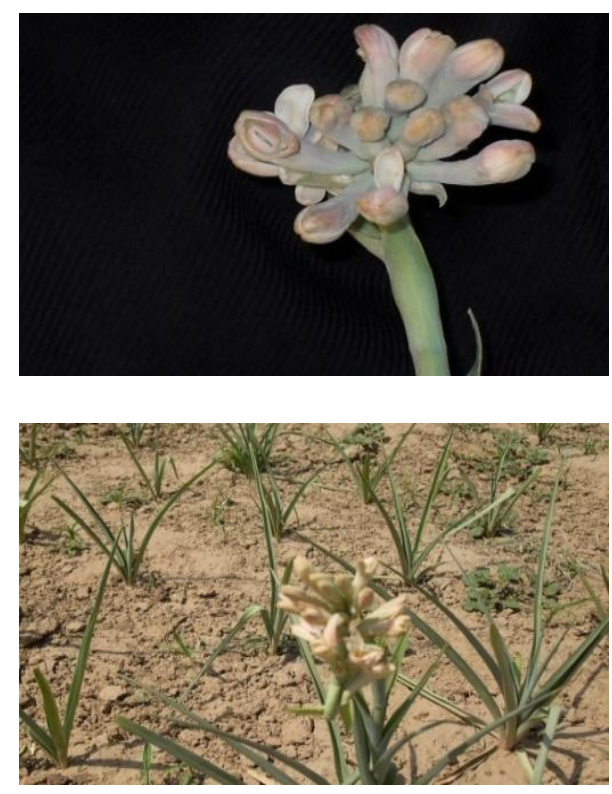

Figure 6:Colour variation induced by gamma irradiation in cv. Prajwal (7.5 Gy) at $\mathrm{B}_{0}$ bulb stage 


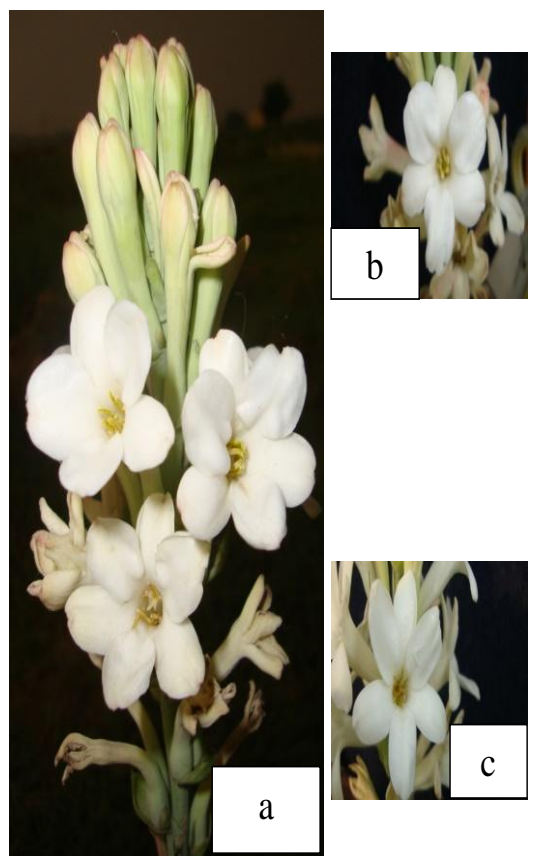

Figure 7. Round shaped petal mutant of cv. Prajwal induced by gamma irradiation (10 Gy) at B2 Bulb stage in VM2 generation (a) \& (b); c) Flower shape of original cv. Prajwal

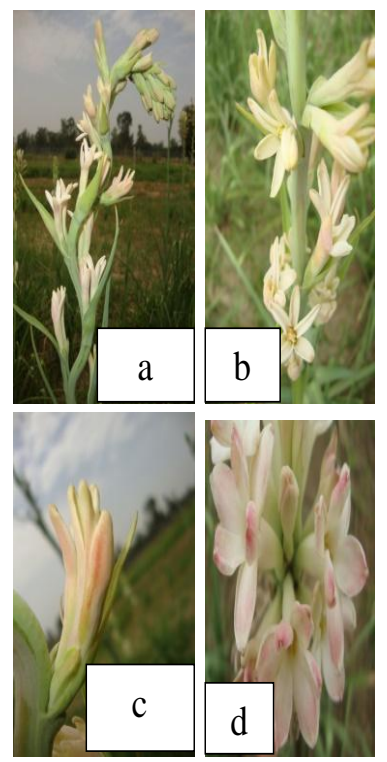

Figure 9. Some of the colour variation in cv. Prajwal at $\mathrm{B}_{0}$ stage by $7.5 \mathrm{~Gy}(\mathrm{a}, \mathrm{b} \& \mathrm{c})$ and 10 Gy (d)

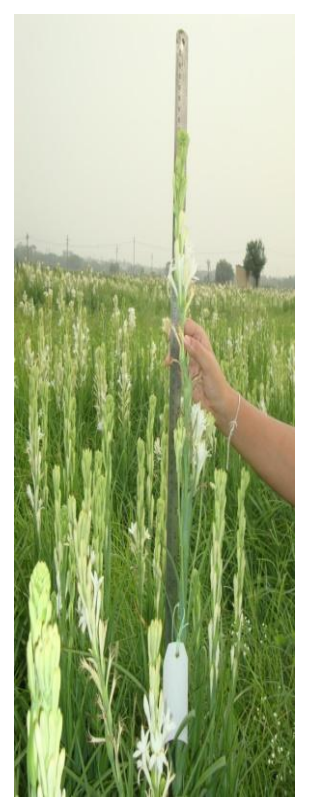

Figure 8.Tall mutant of cv. PhuleRajani at $\mathrm{B}_{0}$ bulb stage by $7.5 \mathrm{~Gy}$ gamma irradiation in $\mathrm{VM}_{2}$ generation

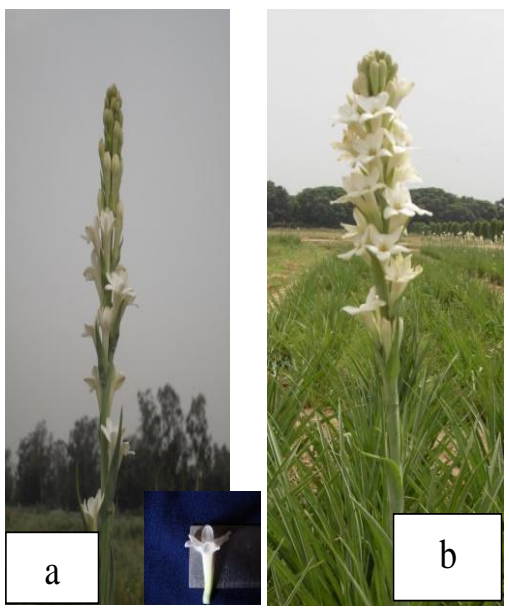

Figure 10. Mutant spike with florets arranged at equally spaced nodes with very small sized florets in cutivarPrajwal at $\mathrm{B}_{0}$ bulb stage by 10 Gy in VM2 generation (a); b) Original spike 
Mutants during $\mathrm{vM}_{1}$ generation and their stability

The below mentioned mutants were reported for the first time in relation with gamma radiation treatment

\section{Tall flowering mutant}

This mutant was identified in 7.5 Gy gamma irradiated freshly harvested bulb stage $\left(\mathrm{B}_{0}\right)$ of cv. Prajwal. The spike was of $146 \mathrm{~cm}$ height (Figure 4a) which is $34 \mathrm{~cm}$ more than the normal Prajwal spike $(112 \mathrm{~cm})$. The spike also contained more number of florets (76) which is also more than the normal Prajwal spike (42). The spike remained straight and no lodging was observed up to opening of last floret.

\section{Dwarf mutant}

This dwarf mutant was derived from cv. PhuleRajani in three weeks after uprooted $\left(\mathrm{B}_{1}\right)$ bulb stage at $7.5 \mathrm{~Gy}$ gamma irradiation. The spike length was reduced up to $34 \mathrm{~cm}$. The number of florets per spike were found as same as that of normal PhuleRajani spike. But the length of the floret got reduced (Figure $4 b)$.

\section{Double spike head mutant}

This mutant was derived from cv. Prajwal in six weeks after uprooted bulb stage $\left(\mathrm{B}_{2}\right)$ at 7.5 Gy of gamma irradiation dose (Figure 5). It was observed that two spike heads were fused from the neck and there was no demarcation on the stock of the spike. It was yielded more number of florets per spike (54) then the control (42).

\section{Flower colour mutant}

Flower colour mutant i.e. slightly pinkish was derived from cv. Prajwal after 7.5 Gy gamma irradiation in $\mathrm{B}_{0}$ bulb stage (Figure 6). The colour was more intense than the normal flower bud of cv. Prajwal which also shows pinkish ting at bud stage. But this mutant retained the colour even after opening of the flower. But the opened florets were not in good form and spike was also not straight.

Bulbs of these mutants were uprooted during mid of January 2010 and stored for 30 days and planted in $1 \times 1 \mathrm{~m}$ sized plots at the end of February 2010. There was no reduction in the per cent germination and survival of the bulbs observed. But all the four mutants were not found stable. The main reason for this could be diplontic selection, which is competition between the mutated cell and the non-mutated neighbor cells. Mutated cell often cannot express itself because it loses the competition within the cell layer (Broerties, 1966).

Mutants in $\mathbf{v M}_{2}$ generation from the primary gamma irradiated population

The below mentioned mutants were derived from the primary gamma irradiated population which was maintained after observing the gamma irradiation effect of $\mathrm{vM}_{1}$ generation. Except variegated leaf mutant other mutants which were observed in $\mathrm{vM}_{2}$ generation are of first of its kind in tuberose induced by gamma irradiation.

\section{Flower shape mutant}

Two flower mutants change in flower shape was derived from cv. Prajwal. In one of the mutant the shape of the petal has been changed from elongated to round shape (Figure 7). All the florets of the spike have showed the same petal shape. This was observed in $\mathrm{B}_{2}$ bulb stage i.e. six weeks after uprooting of bulbs. At 10.0 Gy of gamma irradiation dose. In the second flower shape mutant increased petal length was observed. And the florets were very big than the normal 
floret of cv. Prajwal. This was observed in $\mathrm{B}_{1}$ bulb stage i.e. three weeks after uprooting at 2.5 Gy of gamma irradiation dose.

These finding are similar to the findings of Singh et al., (2013) in Gladiolus.

\section{Tall mutant}

This mutant was derived from the cv. PhuleRajani from freshly harvested bulb stage $\left(\mathrm{B}_{0}\right)$ at $7.5 \mathrm{~Gy}$ gamma irradiation dose. The spikes were grown up to $94 \mathrm{~cm}$ (Figure 8) whereas normal spike is around $70-74 \mathrm{~cm}$ in general.

\section{Flower colour mutant}

This mutant was same as that one which we observed in $\mathrm{vM}_{1}$ generation. This was derived from the same plot at 7.5 Gy gamma irradiation dose in cv. Prajwal from freshly harvested bulb stage $\left(B_{0}\right)$ (Figure 9$)$.

\section{Mutant with higher rachis length}

This mutant was derived from cv. Prajwal from freshly harvested bulb stage $\left(\mathrm{B}_{0}\right)$ at 7.5 Gy gamma irradiation dose. In this mutant the individual florets become small and are arranged at equal space intervals (Figure 10). This kind of mutant could be useful in flower decoration using spike as whole

\section{Variegated leaf mutant}

This mutant was derived from cv. PhuleRajani form freshly harvested bulb stage $\left(\mathrm{B}_{0}\right)$ at $10.0 \mathrm{~Gy}$ gamma irradiation dose. In this mutant white colour band has formed at the middle of the leaf. All the leaves which has emerged from the bulb were showed the same pattern. Similar results was obtained by Banerji et al., in gladiolus crop. This mutant was separated from the mother bulb and transferred to pot and maintained.
These above mentioned mutants could be of putatively stable because these are isolated after the second cycle of the bulb propagation.

When we observed the response of different bulb stages of both the tuberose cultivars for mutation induction by gamma irradiation, the more number of mutants were isolated from the freshly harvested bulbs $\left(\mathrm{B}_{0}\right)$ of both the tuberose cultivars which was flowed by six weeks after uprooted bulbs $\left(\mathrm{B}_{2}\right)$ and we have observed low mutants in three weeks after uprooted bulbs $\left(\mathrm{B}_{1}\right)$. From this study it was found that freshly harvested bulbs of both the tuberose cultivars Prajwal and PhuleRajani are highly suitable for mutation induction either in vivo and also in vitro condition. The gamma irradiation dose 7.5 Gy and 10.0 Gy were found effective for the mutation induction in tuberose cultivars Prajwal and PhuleRajani.

\section{References}

Anu, G., Krishnan, C. K., Rajeevan, P. K., Valsalakumari, P. K. and Saifudeen, N. 2003.Induced mutation in tuberose (Polianthes tuberosa Linn) by gamma rays. A compendium of research papers: National Symposium on Recent Advances in Indian Floriculture, Kerala Agricultural University pp: 255-259.

Bailey, L.H. 1939. The Standard Cyclopedia of Horticulture, Macmillanco, Nr: 2731-33.

Banerji, B. K., Datta S. K. and Sharma S. C. 1994.Gamma irradiation on gladiolus cv. White Friendship.Journal of Nuclear Agriculture Biology, 23 (3): 127-133.

Banerji, B.K., A.K. Dwivedi and S.K. Datta. 2000. Gamma ray induced variability in gladiolus. Abst: National Conference on Gladiolus. NBRI, Lucknow. No. 8.

Bhat, R., N. Upadhaya, A. Chaudhury, A. Raghavan, C. Qiu, F. Wang, H. Wu, J. Mcnally, K. Leiung and B. Till. 2007. Chemical and irradiation induced mutants and tilling. Rice functional genomics, $\mathrm{p}$ 148-180.

Broertjes, C. (1966) Mutation breeding of 
Chrysanthemums. Euphytica, 15: 156-162.

Datta, S. 2000. Role of classical mutation breeding in crop improvement. Daya Pub. House, Delhi. pp. 265-266.

Gorden, S.A. 1957. The effects of ionizing radiations. In: Proceedings of international conference on peaceful uses of Atomic Energy, Geneva, PP 209-12.

Gunkel, J.E. and Sparrow, A.H.1954. Aberrant growth in plants induced by ionizing radiation. Brookhaven Symposium on Biology, 6: 252-279.

Hagberg, A. and Nybom, N. 1954.Reaction of potatoes to $\mathrm{X}$ - irradiation and radiophosphoros. Acta Agriculture Scand. 4: $578-584$.

Hansel H. 1966. Induction of mutations in barley, some practical and theoretical results. Mutations in plant breeding (Proceedings. Panel Viena) IAEA, pp. 117-138.

Katagiri, K. and K.O. Lapins. 1974. Development of gamma irradiated accessory buds of sweet cherry, Prunusavium L. Radiation Botany, 14: 173-178.

Katagiri, K. and Lapins, K.O. 1974. Radiosensitivity in plants, Japanese Journal of Breeding, 22 (3): 153-158.

Kawai, T. and Sato, H. 1966.Some factores modifying the effects of radiation in seed treatment in rice. In: Mutation in Plant Breeding, IAEA, Vienna, pp. 151-171.

M. Buiatti, R. Tesi and M. Molino. 1969. A developmental study of induced somatic mutations in Gladiolus. Radiation Botany, 9 (1); 39-48.

Marek, J.J. 1959. Mutation: Notes on mutation induced by X-ray. The Gladiolus, 29: 138143.
Omar, M.S. 1988. Effect of gamma ray on callus culture and asexual embryogenesis in Phoenix dacryliferal. Plant Mutation Breeding for Crop Improvement. 6 (2): 258264

Rose, J.N. 1903. Amaryllidaceae. Contribution from the United Sates National Herbarium, 8: 8-23.

Singh, A., K. Kumar and K. Anuj. 2013. Studies of gamma irradiation on morphological characters in gladiolus. The Asian Journal of Horticulture 8 (1): 299-303.

Singh, K P., Ganesh B Kadam and Jyothi, R. 2010. Production Manual on tuberose (Polianthes tuberose Linn). Published by Directorate of Floriculture Research, IARI Campus, Pusa, New Delhi, India, pp.1-24.

Skooge, F. 1935. Chemical regulation of growth and organ formation in plants. Symposium, Society of Experimental Biology, 11: 118130.

Sparrow A H., Moses M.J. and Steele R. 1952. Acytological and cytochemical approach to an understanding of radiation damage in dividing cells. British Journal of Radiology, 25: 182-188.

Stienberg, R.A. 1956. Metabolism of inorganic nitrogen by plants. In: Inorganic Nitrogen Metabolism (eds W.D. McElory and B.Glass) John Hopkins Press, Baltimore, pp. $153-158$.

Yekta Navabi, Maryam Norouzi, Mostafa Arab, Shirin Dianati Daylami. 2016. Mutagenesis via Exposure to Gamma-rays in Tuberose (Polianthes tuberosa). Electronic Journal of Biology. 12 (2): 168-172.

\section{How to cite this article:}

Jyothi, R., K.P. Singh, T. Mohapatra and Kiran Kumar, N. 2019. Induction of Novel Mutants and their Stability Using Gamma Irradiation in Tuberose (Polyanthes tuberosa L). Int.J.Curr.Microbiol.App.Sci. 8(08): 1815-1824. doi: https://doi.org/10.20546/ijcmas.2019.808.214 